Analytica Chimica Acta, 63 (1973) 325-339

(C) Elsevier Scientific Publishing Company, Amsterdam - Printed in The Netherlands

\title{
ACID-BASE TITRATIONS IN SOLVENTS OF RELATIVELY LOW DIELECTRIC CONSTANT
}

\author{
M. BOS and E. A. M. F. DAHMEN
}

Department of Chemical Technology, Twente University of Technology, Enschede (The Netherlands) (Reccived 18th August 1972)

The importance of titrations in nonaqueous solvents as an analytical method is increasing; not only has more sophisticated instrumentation become available, but theoretical knowledge about the physicochemical processes which govern titrations in nonaqueous solvents has extended very much in recent years. Especially the titrations of Bronsted acids and bases have been the subject of numerous studies ${ }^{1.2}$, and most applications relate to these particular titrations.

It is of great importance to make a proper choice of the solvent and the titrant when such titrations are applied to the analysis of a given compound, i.e. knowledge about acid-base strengths in the various solvents is an absolute necessity. Only when all equilibria occurring during a neutralization and their corresponding equilibrium constants are known, can one calculate whether this neutralization can be successfully used in an analytical titration. For the more common acids and bases in a number of solvents like acetonitrile ${ }^{3}$, dimethylsulfoxide ${ }^{4}$, dimethylformamide 5 such is indeed the case.

Empirically it has been found that solvents with a relatively low dielectric constant such as acetic acid ${ }^{6}, 1,2$-d ichloroethane ${ }^{7}$ and pyridine ${ }^{8}$, can also be effectively used as a medium for acid-base titrations. Some rules with regard to the choice of a solvent for a particular titration can be found from the classification of the solvent according to Bronsted ${ }^{9.10}$. Here the solvents with a relatively low dielectric constant are classified as numbers 5-8 (cf. Table I).

TABLE I

SOLVENT CLASSES ACCORDING TO BRONSTED 9.10

\begin{tabular}{llll}
\hline Class no. & Acidity & Basicity & Dielectric constant \\
\hline 1 & High & High & High \\
2 & High & Low & High \\
3 & Low & High & High \\
4 & Low & Low & High \\
5 & High & High & Low \\
6 & High & Low & Low \\
7 & Low & High & Low \\
8 & Low & Low & Low \\
\hline
\end{tabular}


It is to be expected that the behaviour during titration of a compound in solvents belonging to the same Bronsted class will not be too different, so that from $\mathrm{p} K_{\mathrm{a}}$ determinations in representatives of each of the Bronsted classes, one can obtain an impression of the usefulness of these solvent classes in acid -base titrations. With that purpose acid-base strengths were determined in the solvents pyridine $^{11.12}$ (class 7), $m$-cresol ${ }^{13}$ (class 5) and 1,2-dichloroethane ${ }^{14}$ (class 8 ). In the evaluation of the results obtained, the following theoretical considerations may serve. The acidity of a compound in a particular solvent can best be expressed as its $\mathrm{p} K_{\mathrm{a}}$ value, the negative logarithm of the equilibrium constant of the overall dissociation:

$$
\mathrm{HX}+\mathrm{SH} \stackrel{\kappa_{\text {ins }}}{\rightleftharpoons} \mathrm{SH}_{2}^{+}+\mathrm{X}^{-}
$$

where $\mathrm{SH}$ is the solvent and $\mathrm{HX}$ an acid. The equilibrium constant is given by

$$
K_{\mathrm{HX}}=\left(a_{\mathrm{SI}_{2}} \cdot a_{\mathrm{X}^{-}}\right) / a_{\mathrm{HX}}
$$

hence

$$
\mathrm{p} K_{\mathrm{ax}}^{\mathrm{HX}}=-\log \left(a_{\mathrm{SH}_{2}} \cdot a_{\mathrm{X}^{-}}\right) / a_{\mathrm{HX}}
$$

One can also write

$$
-R T \ln K_{\mathrm{HX}}=\Delta G^{0}
$$

with

$$
\Delta G^{0}=\Delta H^{0}-T \Delta S^{0}
$$

The difference in $\mathrm{p} K_{\mathrm{a}}$ value of compound $\mathrm{HX}$ in the solvent I and the solvent II now becomes:

$$
\left(\mathrm{p} K_{\mathrm{a}}^{\mathrm{HX}}\right)_{\mathrm{l}}-\left(\mathrm{p} K_{\mathrm{a}}^{\mathrm{HX}}\right)_{\mathrm{II}}=(0.43 / R T)\left\{\Delta G_{\mathrm{l}}^{\mathrm{o}}-\Delta G_{\mathrm{II}}^{\mathrm{o}}\right\}
$$

Combination of eqns. (5) and (6) gives:

$$
\left(\mathrm{p} K_{\mathrm{n}}^{\mathrm{HX}}\right)_{1}-\left(\mathrm{p} K_{\mathrm{a}}^{\mathrm{HX}}\right)_{11}=(0.43 / R T)\left\{\Delta H_{1}^{0}-T \Delta S_{1}^{\mathrm{o}}-\Delta H_{\mathrm{li}}^{0}+T \Delta S_{\mathrm{II}}^{0}\right\}
$$

As an approximation the entropy part is neglected in relation to the enthalpy part. The enthalpy contains an electrical part, because in the dissociation a separation of charges occurs. The electric energy of an ion is given by:

$$
E_{\text {clec }}=\varepsilon^{2} z^{2} / 2 D r
$$

where $\varepsilon$ is the unit charge, $z$ the valency of the ion, $D$ the dielectric constant of the solvent, and $r$ the radius of the ion in solution. For reaction (1) eqn. (8) gives:

$$
\Delta E_{\mathrm{elec}}=N\left\{\frac{\varepsilon^{2} z_{\mathrm{SH}_{i}^{+}}^{2}}{2 D r_{\mathrm{SH}_{2}^{+}}}+\frac{\varepsilon^{2} z_{\mathrm{X}}^{2}-}{2 D r_{\mathrm{X}}-}-\frac{\varepsilon^{2} z_{\mathrm{HX}}^{2}}{2 D r_{\mathrm{HX}}}\right\}
$$

In the comparison of $\mathrm{p} K_{\mathrm{a}}$ values in solvents with the same dielectric constant, the electric energy part can be omitted if it is assumed that the ionic radii remain constant with change of solvent. The difference in $\mathrm{p} K_{\mathrm{u}}$ values of compound $\mathrm{HX}$ in solvent $\mathrm{I}$ and solvent II then reduces to: 


$$
\begin{aligned}
& \left(\mathrm{p}_{\mathrm{n}}^{\mathrm{HX}}\right)_{1}-\left(\mathrm{p} K_{\mathrm{a}}^{\mathrm{HX}}\right)_{\mathrm{II}_{1}}= \\
& \quad(0.43 / R T)\left\{\left(E_{\mathrm{SH}_{2}^{+}}^{0}\right)_{1}+\left(E_{\mathrm{X}^{-}}^{\mathrm{O}}\right)_{1}-\left(E_{\mathrm{HX}}^{\mathrm{o}}\right)_{1}-\left(E_{\mathrm{SH}_{2}^{+}}^{\mathrm{O}}\right)_{11}-\left(E_{\mathrm{X}}^{\mathrm{o}}-\right)_{\mathrm{II}}+\left(E_{\mathrm{HX}}^{\mathrm{o}}\right)_{\mathrm{II}}\right\}
\end{aligned}
$$

If the differences of solvation of the compounds $\mathrm{X}^{-}$as well as $\mathrm{HX}$ between the solvents I and II are neglected, one gets:

$$
\left(\mathrm{p} K_{\mathrm{u}}^{\mathrm{HX}}\right)_{1}-\left(\mathrm{p} K_{\mathrm{u}}^{\mathrm{HX}}\right)_{\mathrm{HI}}=(0.43 / R T)\left\{\left(E_{\mathrm{SH}_{2}^{+}}^{\mathrm{O}}\right)_{1}-\left(E_{\mathrm{SH}_{2}^{+}}^{\mathrm{O}}\right)_{\mathrm{HI}}\right\}
$$

In this case with the approximations stated, the difference of $\mathrm{p} K_{\mathrm{a}}$ of compound HX in the two solvents is completely determined by the difference in proton affinity of the two solvents. Thus it is possible to find the difference in basicity of these solvents under these conditions.

On the other hand, quantitative information about differences in basicity of solvents together with dielectric constant data and eqn. (9), can be used to predict the $\mathrm{p} K_{\mathrm{a}}$ values which are of analytical interest.

\section{$\mathrm{p} K_{\mathrm{a}}$ VALUES IN SOLVENTS WITH A RELATIVELY LOW DIELECTRIC CONSTANT}

A comparison of the $\mathrm{p} K_{\mathrm{a}}$ values of various compounds in the solvents acetic acid, pyridine, $m$-cresol and 1,2-dichloroethane is given in Table II. From the Table it can be seen that for a particular compound, the difference in $\mathrm{p} K_{\mathrm{a}}$ value in two solvents depends on the charge type, even if the dielectric constant of the two TABLE II

\begin{tabular}{|c|c|c|c|c|c|}
\hline \multirow[t]{2}{*}{ Compound } & \multicolumn{5}{|l|}{$p K_{a}$ values } \\
\hline & $\begin{array}{l}\text { Dichloriethane } \\
(D=10.23)\end{array}$ & $\begin{array}{l}11 \text {-Cresol } \\
(D=12.3)\end{array}$ & $\begin{array}{l}\text { Acetic acid } \\
(D=6.13)\end{array}$ & $\begin{array}{l}\text { Pyridine } \\
(D=12.3)\end{array}$ & $\begin{array}{l}\text { Water } \\
(D=78.5)\end{array}$ \\
\hline Perchloric acid & & & $4.87^{\circ}$ & $3^{b}$ & \\
\hline Hydriodic acid & $7.9^{d}$ & $4.4^{\circ}$ & & $3.2^{r}$ & \\
\hline Hydrobromic acid & $8.7^{\mathrm{d}}$ & $4.4^{c}$ & & $4.4^{c}$ & \\
\hline Hydrochloric acid & $10.8^{d}$ & $6.4^{\circ}$ & $8.55^{a}$ & $6.1^{r}$ & \\
\hline Benzenesulfonic acid & $12.1^{d}$ & $6.3^{\circ}$ & & & \\
\hline Picric acid & $13.7^{d}$ & $12.0^{e}$ & $\hat{\mathbf{a}}$ & $3.0^{b}$ & $0.38^{f}$ \\
\hline Iodoacetic acid & $17.6^{d}$ & $13.0^{\mathfrak{r}}$ & & & $3.12^{f}$ \\
\hline Benzoic acid & $20.0^{d}$ & $15.0^{e}$ & & $11.0^{\prime \prime}$ & $4.19^{f}$ \\
\hline Acetic acid & & $16.0^{r}$ & & $12.0^{\prime \prime}$ & $4.75^{r}$ \\
\hline DMAABH $^{+}$ & & $11.0^{*}$ & $8.13^{a}$ & & $3.3^{j}$ \\
\hline Methyl orange $\mathbf{H}^{+}$ & & $11.0^{*}$ & $7.60^{k}$ & & $3.5^{j}$ \\
\hline Strychnine $\mathbf{H}^{\star}$ & $16.0^{d}$ & $13.0^{\circ}$ & & & $8.0^{r}$ \\
\hline Morpholine $\mathrm{H}^{+}$ & $15.0^{4}$ & $12.1^{\circ}$ & & $3.5^{6}$ & $9.6^{f}$ \\
\hline n-Butylamine $\mathrm{H}^{+}$ & $17.0^{d}$ & $13.9^{\circ}$ & $8.59^{h}$ & $5.5^{b}$ & $10.6^{f}$ \\
\hline Triethylamine $\mathrm{H}^{+}$ & $17.7^{d}$ & $14.2^{*}$ & $9.45^{h}$ & $3.8^{b}$ & $10.8^{f}$ \\
\hline Tetramethylguanidine $\mathrm{H}^{+}$ & $21.5^{d}$ & $14.5^{\circ}$ & & $9.6^{b}$ & $12.3^{k}$ \\
\hline Bromophenol blue (2) & $23.8^{d}$ & & & $5.3^{b}$ & $4.1^{J}$ \\
\hline Bromocresol green (2) & $22.2^{d}$ & & & $5.5^{b}$ & $4.9^{j}$ \\
\hline Bromocresol purple (2) & $24.7^{d}$ & & & $7.5^{\prime \prime}$ & $6.4^{J}$ \\
\hline
\end{tabular}

COMPARISON OF $p K_{\mathrm{u}}$ VALUES IN ACETIC ACID, PYRIDINE, m-CRESOL, 1,2-DICHLOROETHANE AND WATER

"Ref. 15. ${ }^{b}$ Ref. 11. ' Ref. 16. "Ref. 14. " Ref. 13. ${ }^{\prime}$ Ref. 17. "Ref. 12. "Ref. 18. ${ }^{\prime}$ Ref. 19. ${ }^{k}$ Present work. 
solvents is the same. This means that the assumption that ionic radii remain constant going from one solvent to another is not entirely justified. The influence of a changing ionic radius upon the $\mathrm{p} K_{\mathrm{a}}$ difference is smallest for acids of the cation-type (see eqn. 9), so that in the determination of basicity differences of solvents, the best thing to do is to take into account the $p K_{u}$ values of these cationic acids. For these compounds the following relationships are valid in approximation:

$$
\begin{aligned}
& \left(\mathrm{p} K_{\mathrm{a}}\right)_{\text {dichlorocthane }}=\left(\mathrm{p} K_{\mathrm{a}}\right)_{\text {m-cresol }}+3 \\
& \left(\mathrm{p} K_{\mathrm{a}}\right)_{m-\text { cresol }}=\left(\mathrm{p} K_{\mathrm{a}}\right)_{\text {acctic acid }}+4 \\
& \left(\mathrm{p} K_{\mathrm{a}}\right)_{\text {acetic acid }}=\left(\mathrm{p} K_{\mathrm{a}}\right)_{\mathrm{pyridine}}+4
\end{aligned}
$$

The basicity of these solvents thus increases in the order

dichloroethane $<m$-cresol $<$ acetic acid $<$ pyridine

If it is assumed that the basicity of dichloroethane is $0 \mathrm{p} K$ units, the basicity of $m$-cresol, acetic acid and pyridine becomes 3,7 and $11 \mathrm{p} K$ units, respectively.

From Table II, it can also be seen that for hydriodic acid, hydrobromic acid and hydrochloric acid, levelling occurs in pyridine and $m$-cresol. For tetramethylguanidine in $m$-cresol there is a basicity levelling.

Comparison of the $\mathrm{p} K_{\mathrm{a}}$ values of an electrically uncharged acid in two solvents with the same dielectric constant, shows that the difference between the $\mathrm{p} K_{\mathrm{a}}$ values is not equal to the difference in basicity of the two solvents. The same holds for anion-type acids. Equation (9) explains this behaviour, especially on the basis of differences in ionic radii.

In order to estimate the $p K_{a}$ value of a compound in one of the solvents of the Brønsted classes $5-8$, which is necessary to find a suitable titration, the following procedure can be used.

(a) Check if a $\mathrm{pK}$ a value of the compound, or a related one, is known in one of the solvents belonging to the Brønsted classes 5-8.

(b) If necessary, extrapolate the value found in step $a$ to the $\mathrm{p} K_{\mathrm{a}}$ value in the solvent to be used. Here it is necessary to take into account the difference in basicity between the various Bronsted classes as well as the influences of difference in dielectric constant and the in. Tuence of the charge type of the compound. Care should also be taken to deal with any levelling.

(c) Should the $\mathrm{p} K_{\mathrm{a}}$ value of neither the compound nor a related one be known in any of the solvents belonging to the Brønsted classes 5-8, then the $p K_{\mathrm{a}}$ value of the compound in water must be extrapolated in the same way as given in step $b$.

\section{ACCURACY OF TITRATIONS IN SOLVENTS WITH A RELATIVELY LOW DIELECTRIC CONSTANT}

In all the cases investigated, the glass electrode behaves in the solvents belonging to the Bronsted classes 5-8, according to the Nernst equation. Potentiometry with the glass electrode is therefore very useful as an indication method for 


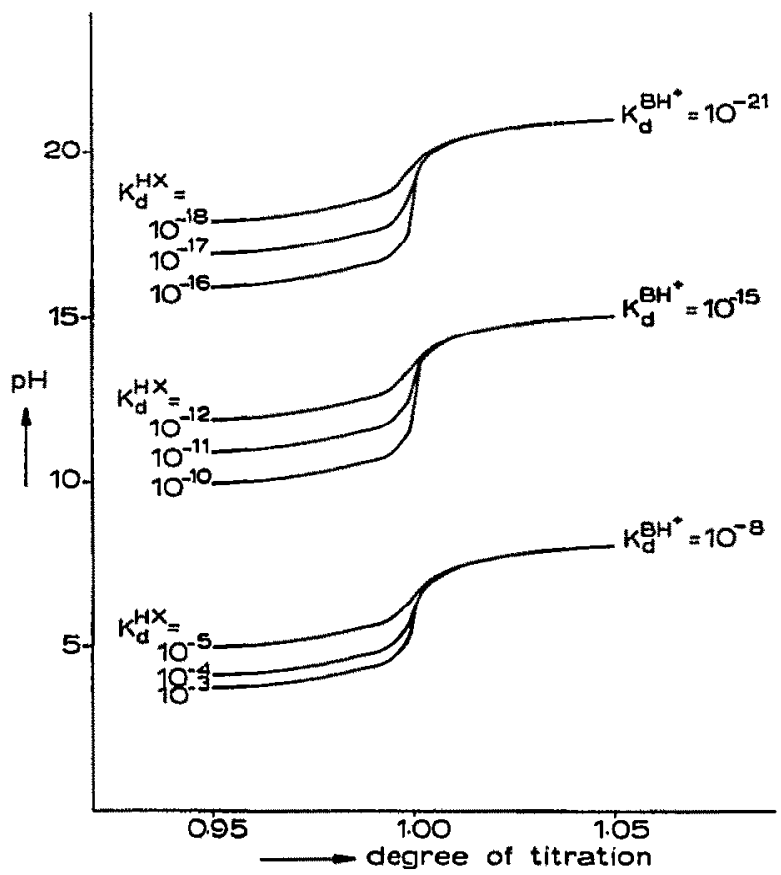

Fig. 1. Simple dissociation. Titration of $0.01 M \mathrm{HX}$ with $0.01 M \mathrm{~B}$.

TABLE III

ACCURACY OF THE TITRATION OF $0.0100 M$ HX WITH $0.0100 M$ B FOR DIFFERENT COMBINATIONS OF $K_{\mathrm{d}}^{\mathrm{HX}}$ AND $K_{\mathrm{d}}^{\mathrm{BH}}{ }^{+}$IN THE CASE OF SIMPLE DISSOCIATION OF $H X$ AND $\mathrm{BH}^{+}$AND FORMATION OF THE ION-PAIR BHX

$\left(K_{\mathrm{d}}^{\mathrm{BHX}}=10^{-5}\right)$

\begin{tabular}{llll}
\hline$K_{\mathrm{d}}^{\mathrm{HX}}$ & $K_{\mathrm{d}}^{\mathrm{pH}}$ & Accuracy $(\%)$ & $\Delta p H(\lambda=0.99-1.01)$ \\
\hline $10^{-18}$ & $10^{-21}$ & \pm 0.15 & 1.74 \\
$10^{-17}$ & $10^{-21}$ & $< \pm 0.10$ & 2.72 \\
$10^{-16}$ & $10^{-21}$ & $\ll \pm 0.10$ & 3.72 \\
$10^{-12}$ & $10^{-15}$ & \pm 0.15 & 1.74 \\
$10^{-11}$ & $10^{-15}$ & $< \pm 0.10$ & 2.72 \\
$10^{-10}$ & $10^{-15}$ & $\leqslant \pm 0.10$ & 3.72 \\
$10^{-5}$ & $10^{-8}$ & \pm 0.15 & 1.72 \\
$10^{-4}$ & $10^{-8}$ & $< \pm 0.10$ & 2.55 \\
$10^{-3}$ & $10^{-8}$ & $\ll \pm 0.10$ & 2.97 \\
\hline
\end{tabular}

acid-base titrations in these solvents, especially as the results are more easily interpreted than with any other indication method.

If it is assumed that the end-point of the titration can be taken as the point of the curve with maximal slope, this end-point can be detected experimentally with an accuracy of $\pm 0.2 \mathrm{pH}$ unit. From theoretical curves, calculated with the computer program EQUIL ${ }^{20}$, the corresponding accuracy of the titration can be found as a 
function of the various equilibrium constants of the reactions that take part in the titration. This is done for a few cases below.

Simple dissociation

For the simple case that the titration can be fully described by the equilibria $\mathbf{H X}=\mathrm{H}^{+}+\mathrm{X}^{-} ; \mathrm{B}+\mathrm{H}^{+}=\mathrm{BH}^{+} ; \mathrm{BH}^{+}+\mathrm{X}^{-}=\mathbf{B H X}$,

the theoretically calculated curves for various combinations of $K_{\mathrm{d}}^{\mathrm{BI}}{ }^{*}$ and $K_{\mathrm{d}}^{\mathrm{HX}}$ with $K_{d}^{\mathrm{BHX}}=10^{-5}$ are given in Fig. 1. Table III shows the accuracy of the titration as a function of $K_{\mathrm{d}}^{\mathrm{HX}}$ and $K_{\mathrm{d}}^{\mathrm{BH}}$.

The influence of the ion-pair dissociation constant $K_{\mathrm{d}}^{\mathrm{BHX}}$ in this case can be seen from Fig. 2; Table IV shows the accuracy of the titration as a function of this $K_{\mathrm{d}}^{\mathrm{BHX}}$.

\section{Differential titration of two acids}

Sometimes, if differences in acidity are great enough, it is possible to determine the separate components in a mixture of acids with different strengths in

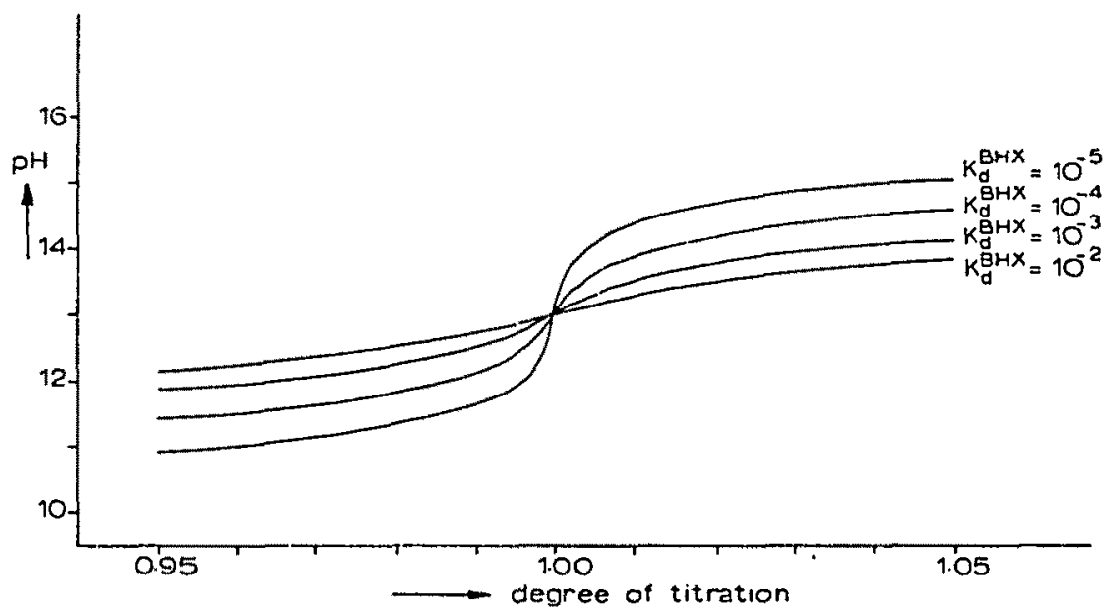

Fig. 2. Titration of $0.00100 M \mathrm{HX}$ with $0.0100 M \mathrm{~B}$ in the case of simple dissociation for various values of $K_{\mathbf{a}}^{\text {Bux. }}$.

TABLE IV

ACCURACY OF THE TITRATION OF $0.0100 M$ HX WITH $0.0100 M$ B AS A FUNCTION OF THE DISSOCIATION CONSTANT OF THE ION-PAIR BHX IN THE CASE OF SIMPLE DISSOCIATION OF HX AND BH ${ }^{+}$

(The difference of $\mathrm{p} K_{s}^{\prime \prime x}$ and $\mathrm{p} K_{u}^{\prime \prime \prime \prime}$ is $4 \mathrm{pK}$ units)

\begin{tabular}{lcl}
\hline$K_{\mathrm{d}}^{\mathrm{inx}}$ & Accuracy $(\%)$ & $\Delta p H(\lambda=0.99-1.01)$ \\
\hline $10^{-3}$ & $< \pm 0.10$ & 2.72 \\
$10^{-4}$ & \pm 0.15 & 1.77 \\
$10^{-3}$ & \pm 0.35 & 0.99 \\
$10^{-2}$ & \pm 0.7 & 0.56 \\
\hline
\end{tabular}


a single titration. In the case of the titration of two acids, HX and HY, with the base $\mathrm{B}$, the titration curve can be calculated with the use of the equilibria:

$$
\begin{aligned}
& \mathrm{HX} \rightleftharpoons \mathrm{H}^{+}+\mathrm{X}^{-} ; \mathrm{HY} \rightleftharpoons \mathrm{H}^{+}+\mathrm{Y}^{-} ; \mathrm{B}+\mathrm{H}^{+} \rightleftharpoons \mathrm{BH}^{+} \\
& \mathrm{BH}^{+}+\mathrm{X}^{-} \rightleftharpoons \mathrm{BHX} ; \mathrm{BH}^{+}+\mathrm{Y}^{-} \rightleftharpoons \mathrm{BHY}
\end{aligned}
$$

Figure 3 shows theoretically calculated curves for this titration with various combinations of $K_{d}^{H X}$ and $K_{d}^{H Y}$. The ion-pair dissociation constants $K_{d}^{111 X}$ and $K_{d}^{111 Y}$ were taken to be $10^{-5}$; for $K_{\mathrm{d}}^{\mathrm{BH}}$ the value $10^{-21}$ was taken. In Table $V$ the accuracy of the titration as a function of the difference in $\mathrm{p} K_{\mathrm{a}}$ value between $H X$ and $H Y$ is given. With greater values for $K_{d}^{\mathrm{BHX}}$ and $K_{\mathrm{d}}^{\mathrm{BHY}}$ (still equal to each other), the accuracy of the second end-point decreases (see Fig. 4 and Table VI).

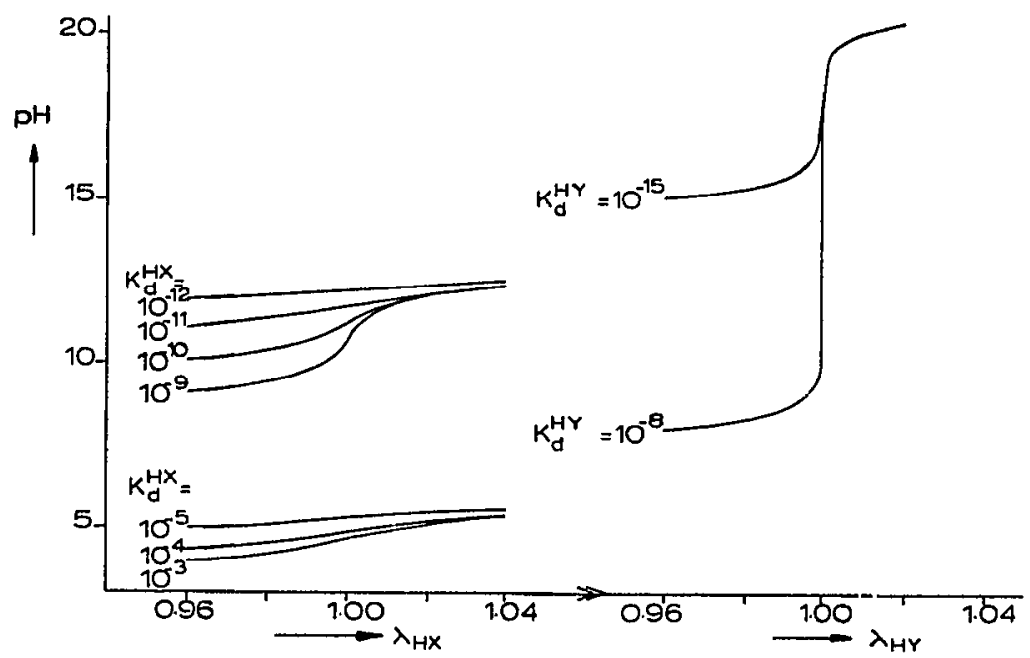

Fig. 3. Titration of $0.005 M \mathrm{HX}$ and $0.005 M$ HY with $0.010 M$ B as a function of $K_{\mathrm{d}}^{\mathrm{HX}}$ and $K_{\mathrm{u}}^{\mathrm{uY}}$. $K_{\mathrm{d}}^{\mathrm{nIIX}}=K_{\mathrm{d}}^{\mathrm{BHY}}=10^{-5} \cdot K_{\mathrm{d}}^{\mathrm{BI \prime}}=10^{-21}$.

\section{TABLE V}

ACCURACY OF THE TITRATION OF A SOLUTION WITH $0.005 M$ HX AND $0.005 M$ HY WITH $0.010 M$ B AS A FUNCTION OF $K_{d}^{\mathrm{HX}}$ AND $K_{\mathrm{d}}^{\mathrm{HY}}$

\begin{tabular}{|c|c|c|c|c|c|}
\hline$K_{\mathrm{d}}^{\mathrm{HX}}$ & $K_{\mathrm{u}}^{\mathrm{HY}}$ & $\begin{array}{l}\text { Accuracy. } \\
\text { lst e.p. }(\%)\end{array}$ & $\begin{array}{l}\Delta p H \\
(\lambda=0.99-1.01) \\
\text { Ist e.p. }\end{array}$ & $\begin{array}{l}\text { Accuracy } \\
\text { 2nd e.p. }(\%)\end{array}$ & $\begin{array}{l}\Delta p H \\
(\lambda=0.99-1.01) \\
\text { 2nd e.p. }\end{array}$ \\
\hline $10^{-9}$ & $10^{-15}$ & \pm 0.10 & 2.01 & $\ll \pm 0.10$ & 5.03 \\
\hline $10^{-10}$ & $10^{-15}$ & \pm 0.3 & 1.08 & $\ll \pm 0.10$ & 5.03 \\
\hline $10^{-11}$ & $10^{-15}$ & \pm 0.9 & 0.43 & $\ll \pm 0.10$ & 5.03 \\
\hline $10^{-12}$ & $10^{-15}$ & e.p. indetectable & 0.14 & $\varangle \pm 0.10$ & 5.03 \\
\hline $10^{-2}$ & $10^{-8}$ & \pm 0.7 & 0.54 & $\ll \pm 0.10$ & 12.03 \\
\hline $10^{-3}$ & $10^{-8}$ & \pm 0.8 & 0.50 & $\ll \pm 0.10$ & 12.03 \\
\hline $10^{-4}$ & $10^{-8}$ & \pm 1.5 & 0.34 & $\ll \pm 0.10$ & 12.03 \\
\hline $10^{-5}$ & $10^{-8}$ & c.p. indetectable & 0.13 & $\ll \pm 0.10$ & 12.03 \\
\hline
\end{tabular}

$\left(K_{\mathrm{d}}^{\mathrm{BHX}}=K_{\mathrm{d}}^{\mathrm{BHY}}=10^{-5}, K_{\mathrm{d}}^{\mathrm{BH} \mathrm{H}^{*}}=10^{-21}\right.$. Simple dissociation of $\mathrm{HX}, \mathrm{HY}$ and $\left.\mathrm{BH}^{+}\right)$ 


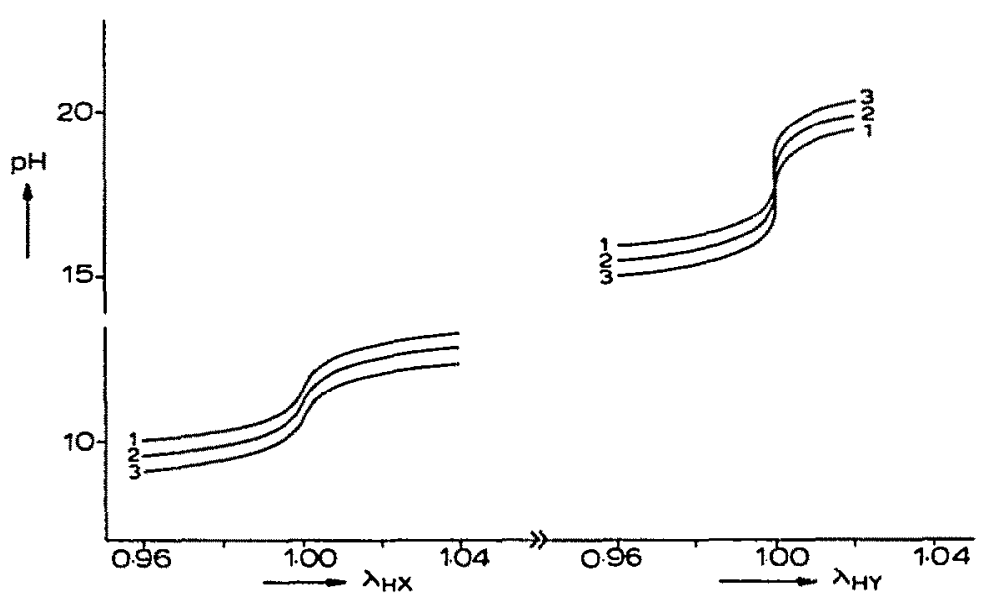

Fig. 4. Titrations of a mixture of $0.005 M H X$ and $0.005 M$ HY with $0.010 M$ as a function of ion-pair dissociation constants $\left(K_{d}^{\mathrm{BHX}}=K_{\mathrm{d}}^{\mathrm{BH}}\right.$ ). $K_{\mathrm{dX}}^{11 \mathrm{X}}=10^{-9}, K_{\mathrm{d}}^{11 Y}=10^{-15}, K_{\mathrm{d}}^{\mathrm{H1}}=10^{-21}$. (1) $K_{\mathrm{d}}^{\mathrm{BHX}}=$ $K_{\mathrm{d}}^{\mathrm{BHY}}=10^{-3} ;$ (2) $K_{\mathrm{d}}^{\mathrm{uHX}}=K_{\mathrm{d}}^{\mathrm{HHY}}=10^{-4} ;$ (3) $K_{\mathrm{d}}^{\mathrm{BHX}}=K_{\mathrm{d}}^{\mathrm{BHY}}=10^{-5}$.

\section{TABLE VI}

ACCURACY OF THE TITRATION OF A SOLUTION $0.005 M$ HX AND $0.005 M$ HY WITH $0.010 M$ B AS A FUNCTION OF THE ION-PAIR DISSOCIATION CONSTANTS

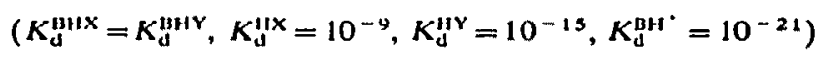

\begin{tabular}{lllll}
\hline$K_{\mathrm{s}}^{\mathrm{BuX}}=$ & $\begin{array}{l}\text { Accuracy } \\
\text { Ist e.p. }(\%)\end{array}$ & $\begin{array}{l}\Delta p H \\
(\lambda=0.99-1.01) \\
\text { Iste.p. }\end{array}$ & $\begin{array}{l}\text { Accuracy } \\
\text { 2nd e.p. }(\%)\end{array}$ & $\begin{array}{l}\Delta p H \\
(\lambda=0.09-1.01) \\
\text { 2nd e.p. }\end{array}$ \\
\hline $10^{-3}$ & \pm 0.10 & 2.01 & $\ll \pm 0.10$ & 5.03 \\
$10^{-4}$ & \pm 0.10 & 2.02 & $\ll \pm 0.10$ & 4.07 \\
$10^{-3}$ & \pm 0.10 & 2.02 & $\ll \pm 0.10$ & 3.21 \\
\hline
\end{tabular}

When the dissociation constant of the sait of the weakest acid $\left(K_{d}^{\mathrm{BHY}}\right)$ is smaller than that of the strongest acid $\left(K_{\mathrm{d}}^{\mathrm{BHX}}\right)$, the accuracy of the determination of the first end-point is less than in the case of equal salt dissociation constants. This happens because the weaker acid starts to react with the base before the first equivalence point. Quantitative data about this are given in Table VII and Fig. 5.

In the case of greater dissociation constants of the salt of the strongest acid $\left(K_{d}^{\mathrm{BHX}}\right)$, the first end-point can be detected less accurately. Although the position of the second equivalence point is dependent upon this dissociation constant, the height of the break in the curve is not; hence the accuracy of the determination of the second end-point does not depend on the value of $K_{d}^{\mathrm{BHX}}$ (see Table VIII and Fig. 6).

\section{Acid dimerization}

The accuracy of the titration is infuenced unfavourably by dimerization of the acid during titration. The titration curve can in this case be calculated with the use of the equilibria: 


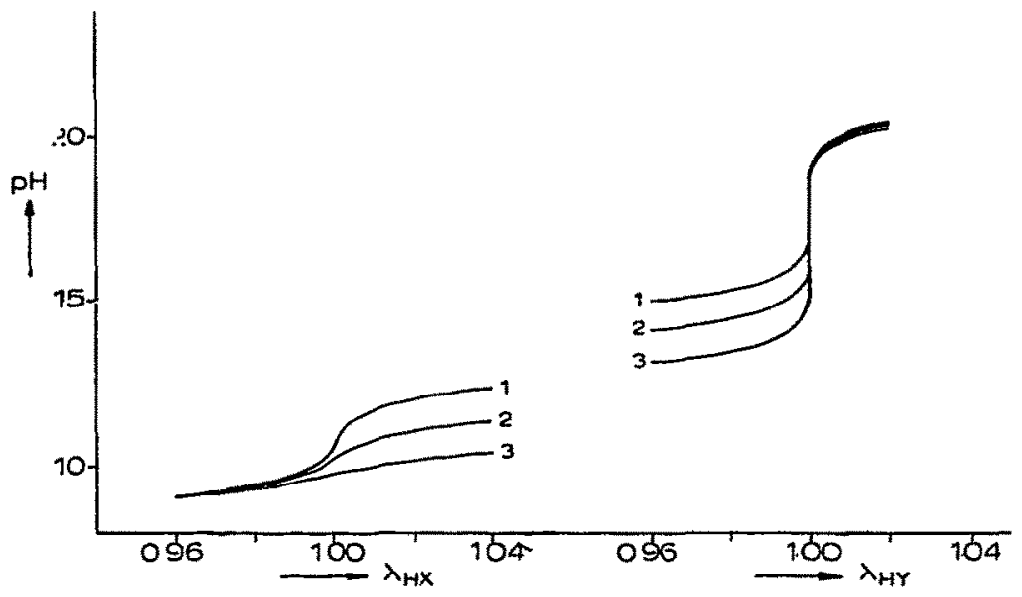

Fig. 5. Titration of a mixture of $0.005 M \mathrm{HX}$ and $0.005 M \mathrm{HY}$ with $0.0100 M$ B for various values of $K_{\mathrm{d}}^{\mathrm{BHY}}$. $K_{\mathrm{d}}^{\mathrm{HX}}=10^{-9}, K_{d}^{\mathrm{HY}}=10^{-15}, K_{\mathrm{gH}}^{\mathrm{BH}}=10^{-21}, K_{\mathrm{d}}^{\mathrm{BHX}}=10^{-5}$. (1) $K_{\mathrm{d}}^{\mathrm{BHY}}=10^{-5} ;(2) K_{\mathrm{d}}^{\mathrm{BHY}}=10^{-6}$; (3) $K_{\mathrm{d}}^{\mathrm{BHY}}=10^{-7}$.

TABLE VII

ACCURACY OF THE TITRATION OF A MIXTURE OF $0.005 M$ HX AND $0.005 M$ HY WITH $0.010 M$ B AS A FUNC'TION OF $K_{d}^{\text {BHY }}$

$\left(K_{d}^{H X}=10^{-9}, K_{d}^{H Y}=10^{-13}, K_{d}^{H H}=10^{-22}, K_{d}^{\mathrm{HAX}}=10^{-5}\right)$

\begin{tabular}{lllll}
\hline$K_{\mathrm{d}}^{\text {uni }}$ & $\begin{array}{l}\text { Accuracy } \\
\text { Ist e.p. }(\%)\end{array}$ & $\begin{array}{l}\Delta p H \\
(\lambda=0.99-1.01) \\
\text { Ist e.p. }\end{array}$ & $\begin{array}{l}\text { Accuracy } \\
\text { 2nd e.p. }(\%)\end{array}$ & $\begin{array}{l}\Delta p H \\
(\lambda=0.99-1.01) \\
2 \text { ind e.p. }\end{array}$ \\
\hline $10^{-5}$ & \pm 0.10 & 2.01 & $\ll \pm 0.10$ & 5.03 \\
$10^{-6}$ & \pm 0.3 & 1.10 & $\ll \pm 0.10$ & 6.01 \\
$10^{-7}$ & \pm 0.9 & 0.44 & $\ll \pm 0.10$ & 7.01 \\
\hline
\end{tabular}

$$
\begin{aligned}
& 2 \mathrm{HX} \rightleftharpoons(\mathrm{HX})_{2} ; \mathrm{HX} \rightleftharpoons \mathrm{H}^{+}+\mathrm{X}^{-} \\
& \mathrm{B}+\mathrm{H}^{+} \rightleftharpoons \mathrm{BH}^{+} ; \mathrm{BH}^{+}+\mathrm{X}^{-} \rightleftharpoons \mathrm{BHX}
\end{aligned}
$$

In the titration curve dimerization shows by a higher start and a smaller slope up to the end-point (see Fig. 7). The effect of the dimerization constant $K_{f}^{(\mathrm{HX})_{2}}$ on the accuracy of the titration is very small. Only in the case $K_{r}^{(\mathrm{HX})_{2}}>10^{4}$, the determination of the end-point becomes less accurate, while owing to curve asymmetry, a systematic error occurs (Table IX).

\section{Homoconjugation and triple ion formation}

Homoconjugation and triple ion formation of the acid lessen the accuracy of the end-point determination of the acid-base titration. Moreover, there is the possibility of an extra inflection point at half-neutralization. The system of equilibria:

$$
\begin{aligned}
& \mathbf{H X} \rightleftharpoons \mathrm{H}^{+}+\mathrm{X}^{-} ; \mathbf{H X}+\mathrm{X}^{-} \rightleftharpoons \mathrm{HX}_{2}^{-} ; \\
& \mathbf{B}+\mathrm{H}^{+} \rightleftharpoons \mathrm{BH}^{+} ; \mathbf{B H}^{+}+\mathrm{X}^{-} \rightleftharpoons \mathbf{B H X}
\end{aligned}
$$




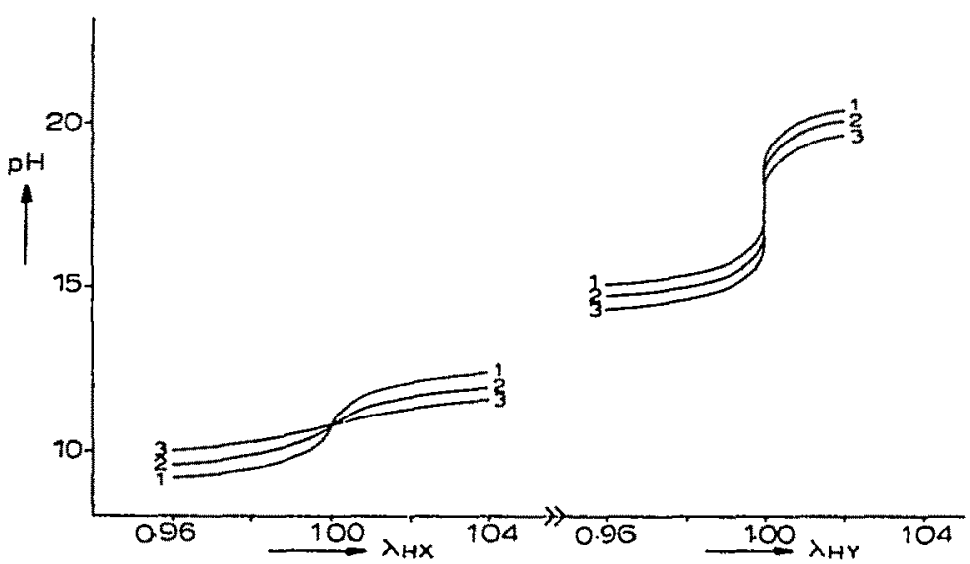

Fig. 6. Titration of a mixture of $0.005 M \mathrm{HX}$ and $0.005 M$ HY with $0.010 M$ B for various values

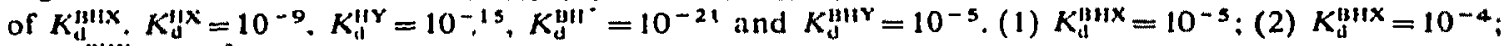
(3) $K_{d}^{311 \times}=10^{-3}$.

TABLE VIII

ACCURACY OF THE END-POINT DETERMINATION IN THE TITRATION OF A MIXTURE OF $0.105 M$ HX AND $0.005 M$ HY WITH $0.010 M$ B AS A FUNCTION OF $K_{d}^{\prime \prime \prime}$

\begin{tabular}{|c|c|c|c|c|}
\hline$K^{m+x}$ & $\begin{array}{l}\text { Accuracy } \\
\text { lst e.p. (") }\end{array}$ & $\begin{array}{l}\Delta p H \\
(\lambda=0.99-J .01) \\
\text { Ist e.p. }\end{array}$ & $\begin{array}{l}\text { Accuracy } \\
2 n d \text { e.p. (\%) }\end{array}$ & $\begin{array}{l}\Delta p H \\
(\lambda=0.99-1.01) \\
2 n d \text { c.p. }\end{array}$ \\
\hline $\begin{array}{l}10^{-5} \\
10^{-4} \\
10^{-3}\end{array}$ & $\begin{array}{l} \pm 0.10 \\
\pm 0.3 \\
\pm 0.7\end{array}$ & $\begin{array}{l}2.01 \\
1.15 \\
0.54\end{array}$ & $\begin{array}{l}\ll \pm 0.10 \\
\ll \pm 0.10 \\
\ll \pm 0.10\end{array}$ & $\begin{array}{l}5.03 \\
5.02 \\
5.01\end{array}$ \\
\hline
\end{tabular}

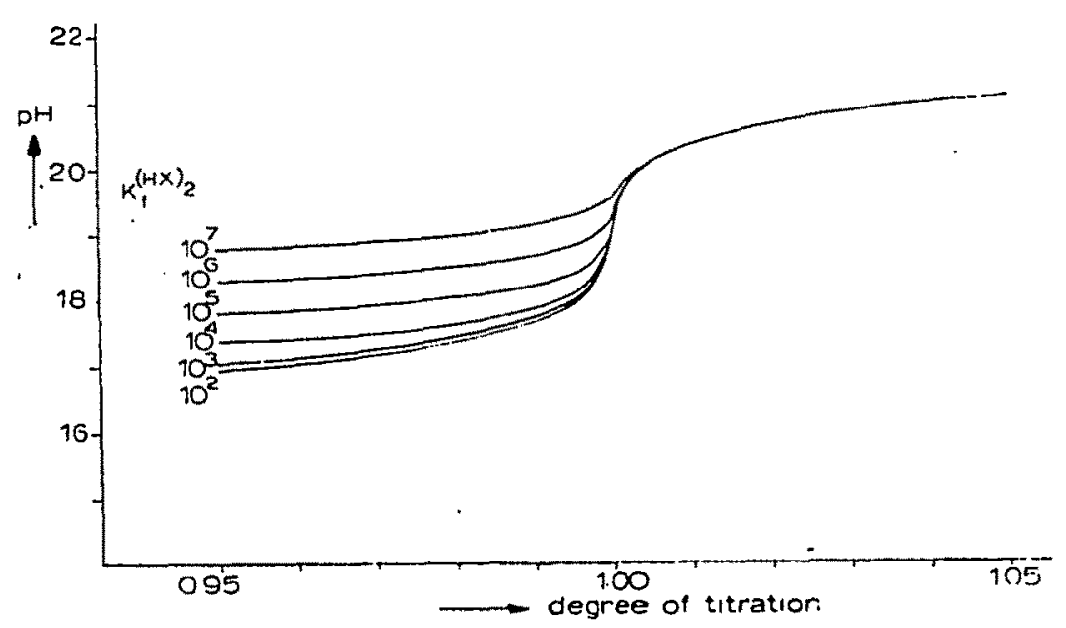

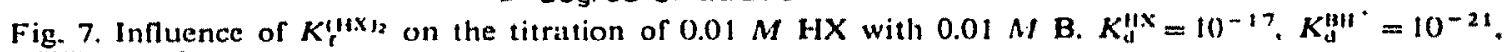
$K_{\mathrm{ilix}}^{\text {likix }}=10^{-5}$. 
TABLE IX

INFLUENCE OF THE DIMERIZATION CONSTANT IN THE TITRATION OF $0.01 M$ HX WITH $0.01 M$ B

$\left(K_{\mathrm{d}}^{\mathrm{uX}}=10^{-17}, K_{\mathrm{d}}^{\mathrm{BI}}{ }^{*}=10^{-21}, K_{\mathrm{d}}^{\mathrm{BHX}}=10^{-5}\right)$

\begin{tabular}{llll}
\hline$K_{\mathrm{r}}^{(1 \mathrm{IX}):}$ & Accures. $(\%)$ & $\Delta p H(\lambda=0.99-1.01)$ & Sistematic error $(\%)$ \\
\hline $10^{2}$ & $< \pm 0.1$ & 2.72 & Negligible \\
$10^{3}$ & $< \pm 0.1$ & 2.69 & Negligible \\
$10^{4}$ & $< \pm 0.1$ & 2.51 & Negligible \\
$10^{5}$ & \pm 0.1 & 2.15 & +0.05 \\
$10^{6}$ & \pm 0.15 & 1.70 & +0.10 \\
$10^{7}$ & \pm 0.20 & 1.23 & +0.20 \\
\hline
\end{tabular}

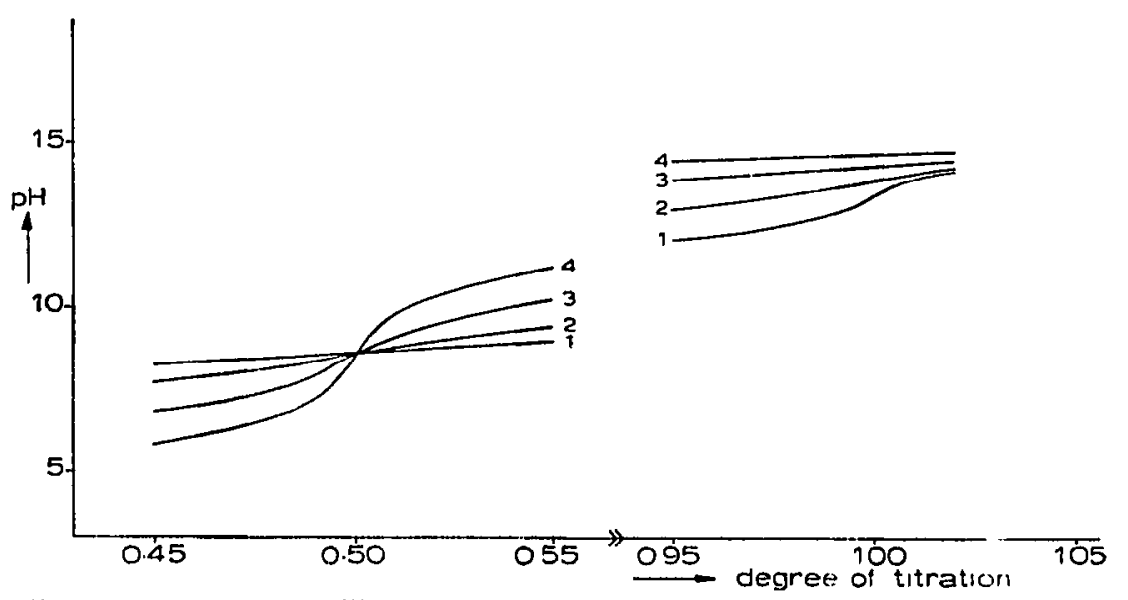

Fig. 8. Influence of $K_{\mathrm{r}}^{11 x_{2}}$ on the titration of $0.01 M$ HX with $0.01 M M$ B. $K_{d}^{1311 \times}=10^{-4}, K_{d}^{11 X}=10^{-10}$, $K_{\mathrm{d}}^{\text {yII }}=10^{-15}$. (1) $K_{\mathrm{f}}^{11 X_{2}}=10^{5} ;$ (2) $K_{1}^{11 X_{1}}=10^{6} ;$ (3) $K_{f}^{11 X_{2}}=10^{7} ;$ (4) $K_{f}^{11 X_{2}}=10^{8}$.

TABLI: $X$

ACCUIRACY OF THE TITRATION OF $0.01 M$ HX WITH $0.01 M$ B AS A FUNCTION OF THE HOMOCONJUGATION CONSTANT $K_{\mathrm{f}}^{1 \mathrm{IX}_{2}}$

$\left(K_{\mathrm{d}}^{\mathrm{HIX}}=10^{-4}, K_{\mathrm{d}}^{\mathrm{HX}}=10^{-10}, K_{\mathrm{d}}^{\mathrm{mi}} \cdot=10^{-15}\right)$

\begin{tabular}{lll}
\hline$p K_{\mathrm{r}}^{\mathrm{HX} x_{2}}$ & Accuracy $(\%)$ & $\Delta p H(\lambda=0.99-1.01)$ \\
\hline-3 & $< \pm 0.1$ & 2.56 \\
-4 & \pm 0.1 & 1.92 \\
-5 & \pm 0.3 & 1.06 \\
-6 & \pm 1 & 0.43 \\
-7 & End-point & 0.17 \\
& indetectable & \\
-8 & End-point & 0.08 \\
& indetectable & \\
\hline
\end{tabular}


TABLE XI

ACCURACY OF THE TITRATION OF $0.01 M$ HX WITH $0.01 M$ B IN THE CASE OF HOMOCONJUGATION $\left(K^{n ! x_{z}}=10^{5}\right)$ COMPARED WITH THE ACCURACY OF THE SAME TITRATION IN CASE OF SIMPLE DISSOCIATION FOR VARIOUS VALUES OF $K_{d}^{\text {BIIX }}$

$\left(K_{d}^{H X}=10^{-10}, K_{d}^{13 \prime \prime}=10^{-15}\right)$

\begin{tabular}{|c|c|c|c|c|}
\hline \multirow[t]{2}{*}{$p K_{d}^{B H X}$} & \multicolumn{2}{|c|}{ Accuracy $(\%)$} & \multicolumn{2}{|c|}{$\Delta p H(\lambda=0.99-1.01)$} \\
\hline & $\begin{array}{l}\text { Homoconj. } \\
K_{\mathrm{r}}^{1 \mathrm{nx} \mathrm{X}_{2}}=10^{5}\end{array}$ & $\begin{array}{l}\text { Simple } \\
\text { dissociation }\end{array}$ & $\begin{array}{l}\text { Homoconj. } \\
K_{\mathrm{f}}^{11 \mathrm{~K}_{\overline{2}}}=10^{5}\end{array}$ & $\begin{array}{l}\text { Simple } \\
\text { dissociation }\end{array}$ \\
\hline 4 & \pm 0.3 & $< \pm 0.1$ & 1.06 & 2.76 \\
\hline 5 & $< \pm 0.1$ & $< \pm 0.1$ & 2.46 & 3.72 \\
\hline 6 & $\ll \pm 0.1$ & $\ll \pm 0.1$ & 4.04 & 4.71 \\
\hline 7 & $\ll \pm 0.1$ & $\ll \pm 0.1$ & 5.61 & 5.70 \\
\hline 8 & $\ll \pm 0.1$ & $\ll \pm 0.1$ & 6.92 & 6.70 \\
\hline
\end{tabular}

TABLE XII

ACCURACY OF THE TITRATION OF $0.01 M$ HX WITH $0.01 M$ B AS A FUNCTION OF $K_{f}^{\mu(n \times) *}$ FOR DIFFERENT COMBINATIONS OF $\mathrm{p} K_{\mathrm{a}}^{\mathrm{m}} \cdot$ AND $\mathrm{p} K_{\mathrm{a}}^{\mathrm{HX}}$

$\left(K_{\mathrm{s}}^{\mathrm{B} n \mathrm{X}}=10^{-5}\right)$

\begin{tabular}{lllll}
\hline$p K_{\mathrm{u}}^{\mathrm{u} \prime \prime}$ & $p K_{\mathrm{u}}^{\text {HX }}$ & $p K_{\mathrm{f}}^{\text {Bu(1X)1 }}$ & Accuracy $(\%)$ & $\Delta p H(\lambda=0.99-1.01)$ \\
\hline 21 & 17 & -2 & $< \pm 0.10$ & 2.56 \\
21 & 17 & -3 & \pm 0.10 & 1.97 \\
21 & 17 & -4 & \pm 0.30 & 1.11 \\
21 & 17 & -5 & \pm 1.0 & 0.45 \\
21 & 17 & -6 & $> \pm 2$ & 0.15 \\
21 & 15 & -5 & \pm 0.10 & 2.05 \\
21 & 15 & -6 & \pm 0.30 & 1.12 \\
21 & 15 & -7 & \pm 1.0 & 0.44 \\
\hline
\end{tabular}

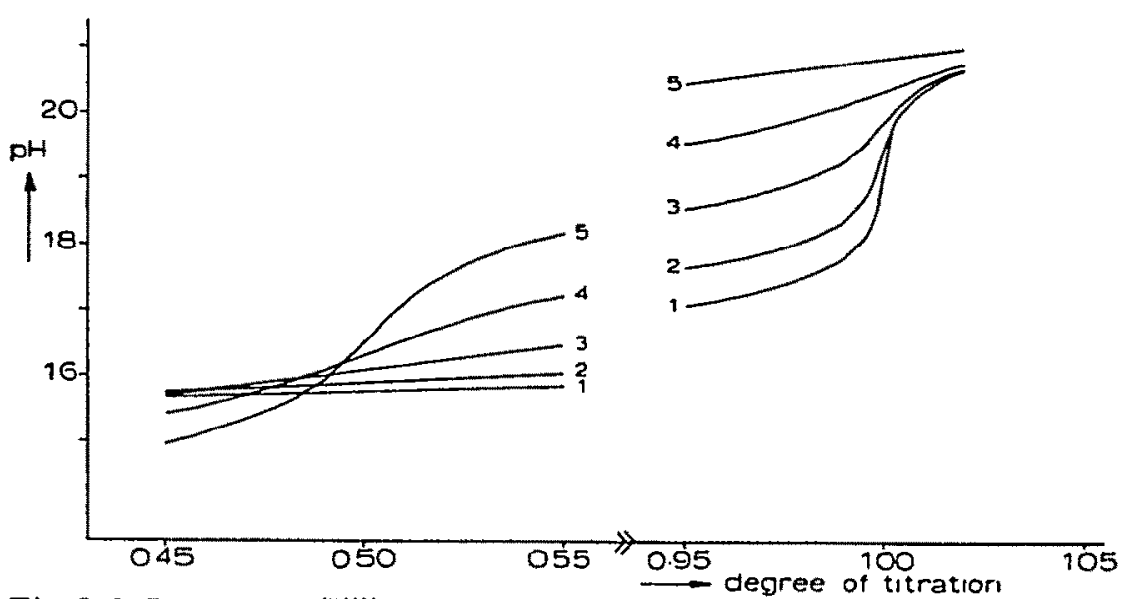

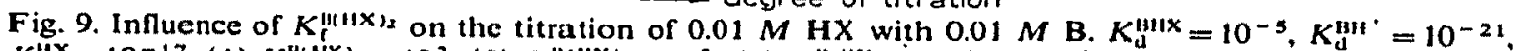

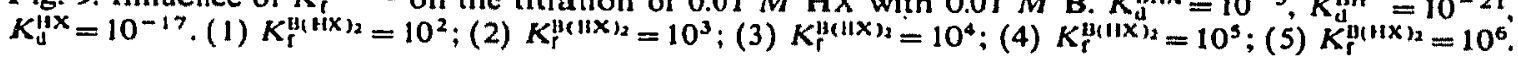


gives the titration curves represented in Fig. 8. The accuracy of the end-point determination for various values of $K_{\mathrm{f}}^{\mathrm{HX}_{\mathbf{2}}^{-}}$is given in Table X. Homoconjugation has a smaller effect when the dissociation constants of the acid and the salt BHX are small (Table XI).

Formation of 2:1 acid-base complex

In inert solvents during acid-base titrations, a $2: 1$ acid-base complex is sometimes formed (e.g. carboxylic acids in 1,2-dichloroethane). This makes the detection of the end-point more difficult. In this case the titration can be described by the equilibria:

$$
\begin{aligned}
& \mathrm{HX} \rightleftharpoons \mathrm{H}^{+}+\mathrm{X}^{-} ; \mathrm{B}+\mathrm{H}^{+} \rightleftharpoons \mathrm{BH}^{+} ; \\
& \mathrm{BH}^{+}+\mathrm{X}^{-} \rightleftharpoons \mathrm{BHX} ; \mathrm{BHX}+\mathbf{H X} \rightleftharpoons \mathrm{B}(\mathrm{HX})_{2} .
\end{aligned}
$$

Theoretical curves for various values of $K_{f}^{\mathrm{B}(\mathrm{HX})_{2}}$ are given in Fig. 9. Here an extra inflection point at half-neutralization is also possible. The accuracy of the endpoint determination for this titration is shown in Table XII.

\section{DISCUSSION}

The specifications which the equilibrium constants should meet in the different cases for a titration accuracy of $\pm 0.1 \%$ are summarized in Table XIII. It should be noted, however, that for many purposes less accurate results are sufficient, and for titrations with solutions with concentrations higher than $0.01 M$ the requirements for the equilibrium constants are less severe. Complex formation, like homoconjugation, etc. has an unfavourable influence on the accuracy of a titration. It is clear that to find a suitable solvent for a particular titrimetric analysis, one always has to take into account the chance of the occurrence of such complexes and the effect of these phenomena on the accuracy of the titration. Generally complications of this kind are rare in solvents with a high $\mathbf{H}$-bond formation capacity. However, in such a solvent triple ion formation may occur.

TABLE XIII

CONDITIONS WITH REGARD TO THE CONSTANTS OF ACID-BASE EQUILIBRIA IN SOLVENTS WITH A RELATIVELY LOW DIELECTRIC CONSTANT FOR A TITRATION

\begin{tabular}{|c|c|}
\hline Type of equilibrium reactions & Conditions for accuracy $\pm 0.1 \%$ \\
\hline Simple dissociation of acid and protonated base & $\mathrm{p} K_{\mathrm{a}}^{\mathrm{BH}}-\mathrm{p} K_{\mathrm{a}}^{\mathrm{HX}}+\mathrm{p} K_{\mathrm{d}}^{\mathrm{BHX}} \geqslant \dot{9}$ \\
\hline $\begin{array}{l}\text { Differential titration of two acids } \mathrm{HX} \text { and } \mathrm{HY} \\
\mathrm{p} K_{\mathrm{a}}^{\mathrm{HX}}<\mathrm{p} K_{\mathrm{a}}^{\mathrm{HY}}\end{array}$ & $\begin{array}{l}\mathrm{p} K_{\mathrm{a}}^{\mathrm{HY}}-\mathrm{p} K_{\mathrm{u}}^{\mathrm{HX}}+\left|\mathrm{p} K_{\mathrm{d}}^{\mathrm{nuX}}-\mathrm{p} K_{\mathrm{d}}^{\mathrm{pHY}}\right| \geqslant 6 \\
\text { and } \\
\mathrm{p} K_{\mathrm{a}^{\mathrm{B}}}^{\mathrm{BI} \cdot}-\mathrm{p} K_{\mathrm{a}}^{\mathrm{HY}}+\mathrm{p} K_{\mathrm{d}}^{\mathrm{BHY}} \geqslant 9\end{array}$ \\
\hline Homoconjugation of the acid (formation of $\mathrm{HX}_{2}^{-}$) & 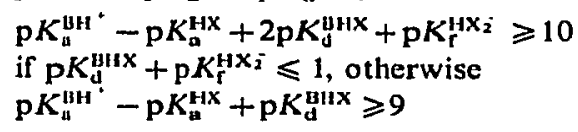 \\
\hline 2:1 Acid-base complex formation $\left(\mathrm{B}(\mathrm{HX})_{2}\right)$ & 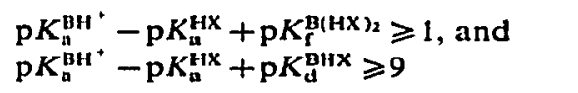 \\
\hline Dimerization of the acid (formation of $(\mathrm{HX})_{2}$ ) & $\begin{array}{l}\mathrm{p} K_{a}^{\mathrm{BH}}{ }^{\prime}-\mathrm{p} K_{\mathrm{a}}^{\mathrm{HX}}+\mathrm{p} K_{\mathrm{d}}^{\mathrm{BuX}} \geqslant 9 \text { and } \\
K_{\mathrm{f}}^{(+\mathrm{HX})_{2}}<10^{3}\end{array}$ \\
\hline
\end{tabular}
ACCURACY OF $\pm 0.1 \%$ 
In comparison to solvents with higher dielectric constants, the solvents belonging to the Bronsted classes 5-8 offer some special advantages in acid-base titrations. For the same titration accuracy, the difference between the $p K_{a}$ values of the acid and the protonated base can be much smaller, which makes it possible to use mild stable titrants. Homoconjugation as well as triple ion formation does not much affect the accuracy of the titrations.

The authors wish to thank Mrs. A. L. den Herder for preparing the manuscript and Mr. R. H. Arends for the drawings.

SUMMARY

From a comparison of the $\mathrm{p} K_{\mathrm{a}}$ values of various compounds in the solvents 1,2-dichloroethane, $m$-cresol, acetic acid and pyridine, the differences in basicity of these solvents could be determined. If the basicity of 1,2-dichloroethane is taken as $0 \mathrm{pK}$ units, the basicities of $m$-cresol, acetic acid and pyridine were found to be 3,7 and $11 \mathrm{p} K$ units, respectively. It is shown how these differences in basicity can serve to predict $\mathrm{p} K_{\mathrm{a}}$ values in solvents belonging to the Bronsted classes 5-8. Theoretical titration curve calculations gave the conditions for the equilibrium constants under which the acid-base titration accuracy is $\pm 0.10 \%$ :

(a) simple dissociation:

$\mathrm{p} K_{\mathrm{il}}^{\mathrm{BH}}-\mathrm{p} K_{\mathrm{a}}^{\mathrm{HX}}+\mathrm{p} K_{\mathrm{d}}^{\mathrm{BHX}} \geqslant 9$

(b) differential titration of two acids $\mathrm{HX}$ and $\mathrm{HY}$ :

$$
\mathrm{p} K_{\mathrm{a}}^{\mathrm{HY}}-\mathrm{p} K_{\mathrm{a}}^{\mathrm{HX}}+\left|\mathrm{p} K_{\mathrm{d}}^{\mathrm{BHX}}-\mathrm{p} K_{\mathrm{d}}^{\mathrm{HHX}}\right| \geqslant 6 \text { and } \mathrm{p} K_{\mathrm{a}}^{\mathrm{BH}}-\mathrm{p} K_{\mathrm{u}}^{\mathrm{HY}}+\mathrm{p} K_{\mathrm{d}}^{\mathrm{HIY}} \geqslant 9
$$

RÉSUMÉ

Une étude est effectuée sur des titrages acide-base dans des solvants, de constante diélectrique relativement faible. Des calculs basés sur une courbe de titrage théorique ont donné les conditions pour des constantes d’équilibre, offrant $\pm 0.10 \%$ d'exactitude, de titrage acide-base:

dissociation simple:

$\mathrm{p} K_{\mathrm{a}}^{\mathrm{uH}}-\mathrm{p} K_{\mathrm{a}}^{\mathrm{ux}}+\mathrm{p} K_{\mathrm{d}}^{\mathrm{uHx}} \geqslant 9$;

titrage différentiel de deux acides $\mathrm{HX}$ et $\mathrm{HY}$ :

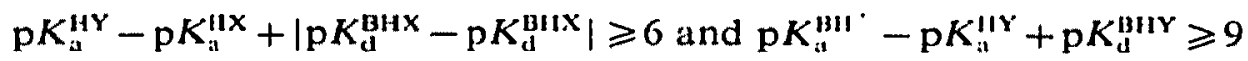

\section{ZUSAMMENFASSUNG}

Durch Vergleich der $\mathrm{p} K_{\mathrm{a}}$-Werte verschiedener Verbindungen in den Lösungsmitteln 1,2-Dichloräthan, in-Kresol, Essigsäure und Pyridin konnten die Differenzen in der Basizität dieser Lösungsmittel bestimmt werden. Wenn die Basizität von 1,2-Dichloräthan gleich 0 pK-Einheiten gesetzt wird, ergeben sich für $m$-Kresol, Essigsäure und Pyridin die Basizitaiten 3,7 und 11 pK-Einheiten. Es wird gezeigt, 
wie diese Basizitätsunterschiede dazu dienen können, die $\mathrm{p} K_{\mathrm{t}}$-Werte in Lösungsmitteln vorherzusagen, die den Bronsted-Klassen 5-8 angehören.

Theoretische Berechnungen der Titrationskurven ergaben die Bedingungen für die Gleichgewichtskonstanten, unter denen die Genauigkeit der Säure-BaseTitration $\pm 0.10 \%$ ist : einfache Dissoziation:

$\mathrm{p} K_{\mathrm{a}}^{\mathrm{BH}}-\mathrm{p} K_{\mathrm{a}}^{\mathbf{H X}}+\mathrm{p} K_{\mathrm{d}}^{\mathrm{HHX}} \geqslant 9$

differentielle Titration zweier Säuren HX und HY: $\mathrm{p} K_{\mathrm{a} 1}^{\mathrm{HY}}-\mathrm{p} K_{\mathrm{a}}^{\mathrm{HX}}+\left|\mathrm{p} K_{\mathrm{d}}^{\mathrm{BHX}}-\mathrm{p} K_{\mathrm{d}}^{\mathrm{BHX}}\right| \geqslant 6$ und $\mathrm{p} K_{\mathrm{a}}^{\mathrm{BH} \mathrm{H}^{+}}-\mathrm{p} K_{\mathrm{a}}^{\mathrm{HY}}+\mathrm{p} K_{\mathrm{d}}^{\mathrm{BHY}} \geqslant 9$.

\section{REFERENCES}

1 G. A. Harlow and D. H. Morman, Anal. Chem., 38 (1966) 485R; 40 (1968) 418 R.

2 J. J. Lagowski, Anal. Chem., 42 (1970) 305R; 44 (1972) S24R.

3 I. M. Kolthoff, S. Bruckenstein and M. K. Chantooni, J. Amer. Chem. Soc., 83 (1961) 3927.

4 I. M. Kolthoff and T. B. Reddy, Inorg. Chem., 1 (1962) 189.

5 I. M. Kolthoff, M. K. Chantooni and H. Smagowski, Anal. Chem., 42 (1970) 1622.

6 I. M. Kolthoff and S. Bruckenstein, J. Amer. Chem. Soc., 78 (1956) 1.

7 H. K. Hall, Jr., J. Phys. Chem., 60 (1956) 63.

8 C. A. Streuli and R. R. Miron, Allal. Chem., 30 (1958) 1978.

9 J. N. Bronsted, Chem. Ber., 61 (1928) 2049.

10 M. M. Davis, Acid-Base Behaviour in Aprotic Organic Solvents, NBS Monograph 105,1968, p. 9.

11 M. Bos and E. A. M. F. Dahmen, Alual. Chim. Acta, 53 (1971) 39.

12 M. Bos and E. A. M. F. Dahmen, Anal. Chim. Acta, 55 (1971) 285.

13 M. Bos and E. A. M. F. Dahmen, Anal. Chim. Acta, 57 (1971) 361 .

14 M. Bos and E. A. M. F. Dahmen, Anal. Chim. Acta, 63 (1973) 183.

15 S. Bruckenstein and I. M. Kolthoff, J. Amer. Chem. Soc., 78 (1956) 2974.

16 L. M. Mukherjee, J. J. Kelly, W. Baranetzky and J. Sica, J. Phys.- Chem., 72 (1968) 3410.

17 R. C. Weast. S. M. Selby and C. D. Hodgman, Handbook of Chemist,y and Physics, The Chemical Rubber Co., Cleveland, 1964, D 76.

18 O. W. Kolling, Anal. Chem., 44 (1972) 414.

19 L. Meites, Handbook of Analyticul Chemistry, McGraw Hill, New York, 1st Ed., 1963, Table 3-36.

20 M. Bos and H. Q. J. Mecrshoek, Anal. Chim. Acta, 61 (1972) 185. 